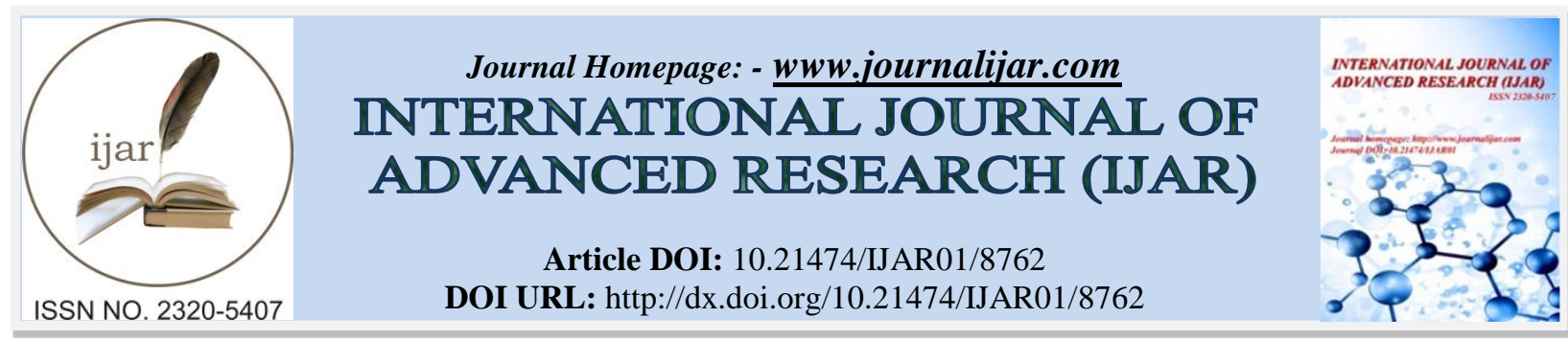

RESEARCH ARTICLE

\title{
KORA COMMUNITY AND THEIR EDUCATION IN WEST BENGAL: AN ETHNOGRAPHIC STUDY.
}

\author{
Biswajit Goswami ${ }^{1}$ and Swami Tattwasarananda ${ }^{2}$. \\ 1. M. Phil research scholar, Ramakrishna Mission Sikshanamandira, Belur math, Howrah. \\ 2. Professor, Ramakrishna Mission Sikshanamandira, Belur math, Howrah.
}

\section{Manuscript Info}

\section{Manuscript History}

Received: 20 January 2019

Final Accepted: 22 February 2019

Published: March 2019

Key words:-

Education, Kora community, West Bengal.

\begin{abstract}
The present study is about the Kora tribal community and their education in West Bengal. According to the Second Amendment Bill 2011 of the Constitution of India (Scheduled Tribes orders) - "Tribals follow some specific criterion like having primitive traits, distributive culture geographical isolation, shyness at contact with the community at large and backwardness". The study was delimited to two districts of West Bengal, namely Bankura and Purulia. The present ethnographer used traditional ethnographic method along with different secondary sources like books, journal, reports, internet etc.
\end{abstract}

Copy Right, IJAR, 2019,. All rights reserved.

\section{Introduction:-}

The present study is about the education of one of the distinctive tribe, the Kora in eastern India. According to the Second Amendment Bill 2011 of the Constitution of India (Scheduled Tribes orders) - "Tribals follow some specific criterion like having primitive traits, distributive culture geographical isolation, shyness at contact with the community at large and backwardness". In general usage, the word "tribe" is taken to denote a primary aggregate of people living in a primitive or barbarous condition under a headman or chief. The unnecessary moralistic overtones that this usage implies can be avoided or minimized by the use of the expression "tribal society", which is to be preferred to such synonyms as "primitive society" or "preliterate society". At the same time, the word "tribe" need not be discarded. Indeed, it has become a technical term denoting a territorially defined political unit, a usage that recalls the original Latin use of the word for the political divisions or patrician orders of the Roman state.

Traditional views distinguish tribal and modern society in terms of imputed differences in their legal and political institutions. Morgan (1877) saw tribal society as having social, but not political organization. A judgment echoed by Sidgwick (1891) contrasted the territorial foundations of the modern state with what they considered to be the kinship basis of tribal societies. Maine regarded tribal emphasis on the status structure (ascribed through birth) to be dominant over relations of voluntary contract that could be achieved by skill or effort. This assessment, of course, formed the basis for the great legal historian's famous aphorism expressing the transition from tribal to modern institutions in terms of the "movement of the progressive societies" from status to contract. Such anthropologists as Gluckman (1955) and Schapera (1938) have made fundamental contributions to the study about contractual relations of a kind in the idiom of kinship.

While taking account of the implications of such homely synonyms as "simple society," "preindustrial society," or "folk society," a satisfactory characterization of tribal society must therefore concentrate upon criteria of form rather than of content. The most useful general criterion is that of "scale" (Wilson \& Wilson 1945). Ideally, tribal societies

Corresponding Author:-Biswajit Goswami.

Address:-M. Phil research scholar, Ramakrishna Mission Sikshanamandira, Belur math, Howrah. 
are small in scale and are restricted in the spatial and temporal range of their social, legal, and political relations, and possess a morality, religion, and world view of corresponding dimensions. Tribal societies exhibit a remarkable economy of design and have a compactness and self-sufficiency lacking in modern society. Tribal societies are supremely ethnocentric.

Economic relations are usually of the subsistence type, although trade and barter often extend outside the community. At the same time, economic differentiation and specialization are not developed, and by modern standards technological knowledge and environmental control remain restricted. Ideally, indeed, a position of socioeconomic equilibrium has been attained in relation to environmental conditions. In these circumstances social change tends to be on a limited scale, reproducing rather than drastically altering the existing order, and innovations are profoundly affected by the established institutions of society.

Yet the isolation and unchanging nature of tribal communities must not be exaggerated; it must be remembered that knowledge of tribal life derives mainly. Even where the history of a tribal society is not known with any certainty, the ebb and flow of contact and influence between cultures is too widespread a phenomenon to be denied on the basis of negative evidence alone. As Forde (1934, p. 466) very properly emphasized, the diffusion of technical, moral, and aesthetic ideas is something that all societies have experienced to some degree. Indeed, contact by either peaceful penetration or conquest, has, in many cases, wrought far-reaching, and often radical, changes in material techniques, values, and social institutions. If tribal societies are to be regarded as having achieved a state of balance with their physical and social surroundings, they must be understood to be in dynamic rather than static equilibrium. Only when these qualifications are accepted in "tribal society" a useful working concept that applies to a wide range of actual communities, existing as they do in reality in both time and space.

The tribes in India have been influenced by certain traditions of the communities around them. Major neighboring community in all the areas has always been Hindus. As a result from the very period there have been several points of contact between the Hindus of the area and tribal communities living within it. The nature and extent of contact the pattern of mutual participation and characteristics of revitalization movements have been different in different parts of India.

The word 'KORA' has got a significant meaning. It signifies earth digging. So it becomes quite obvious that the profession that these KORA is related to cultivation. "The caste (Kora believes tank digging, road making and earth work generally to be their characteristics. Profession and it may be surmised that their adoption of a comparatively degraded occupations, necessarily involving a more or less wondering Manner of life may been the cause which lad to their separation from the Mundas, who are above all things settled agriculturists, conspicuous for their attachment to their original villages" (Risley: 1891, 506-507) As per 2011 census report, in the state at West Bengal the total no. of scheduled tribes was 5,296,953 (Rural - 4, 8555,115 Urban- 441,838). Literacy rates at tribes (2011) 68.2\% male, $47.7 \%$ female in West Bengal.

\section{Objectives of the study:}

To study the origin and tradition and historical development of KORA community in West Bengal in general and Bankura and Purulia district in particular.

\section{Study area:}

The present study had been restricted to Bankura and Purulia districts of West Bengal. From these two districts only four blocks had been taken- two from Bankura (Chatna and Hirbandh) and two from Purulia (Puncha and Manbazar) district. Only Kora tribe had been taken under consideration. The other communities of the tribals had not been taken in this study.

\section{Methodology of the research:-}

The present researcher used traditional ethnographic method to document the objective of the study along with secondary sources likes books, journals, reports and internet.

\section{Findings and discussion:-}

The major findings are given below regarding the objective of the study:

Table 1: Educational Status of Kora Community of Hirbandh Block, Bankura District BLOCK-1(HIRBANDH) 


\begin{tabular}{|l|l|l|l|l|l|l|}
\hline Illiterate & Primary & M.P & H.S & B.A & P.G & Total \\
\hline 6 & 5 & 12 & 5 & 2 & 0 & 30 \\
\hline
\end{tabular}

Source: Field Study

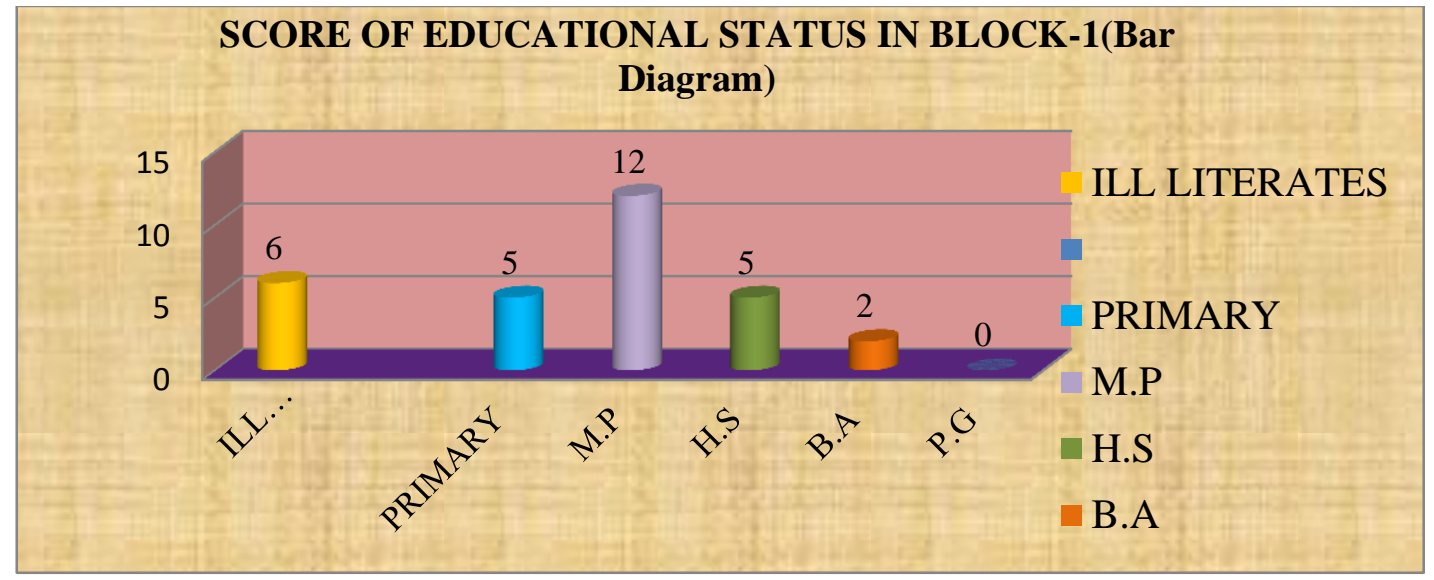

Figure-1 (Source-Field Study).

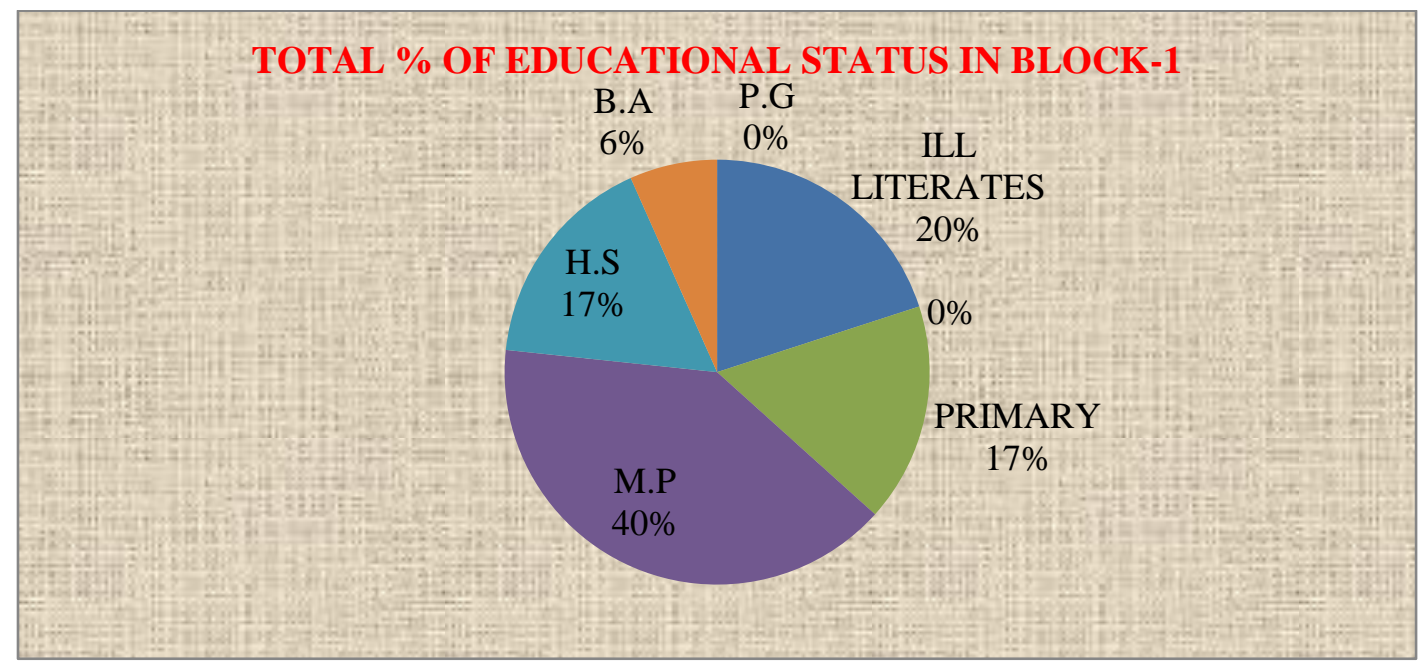

Figure-2 (Source-Field Study)

Table 2: Educational Status With Various Age Group In Hirbandh Block

\begin{tabular}{|c|c|c|c|c|c|c|c|}
\hline \multicolumn{8}{|c|}{ Educational Status With Various Age Group In Hirbandh Block } \\
\hline Age Group & Illiterates & Primary & M.P & H.S & B.A & P.G & Total \\
\hline 50 & 4 & 4 & 2 & 0 & 0 & 0 & 10 \\
\hline $40-50$ & 0 & 0 & 5 & 2 & 0 & 0 & 7 \\
\hline $30-40$ & 1 & 0 & 3 & 3 & 2 & 0 & 9 \\
\hline $20-30$ & 1 & 1 & 2 & 0 & 0 & 0 & 4 \\
\hline Total & 6 & 5 & 12 & 5 & 2 & 0 & 30 \\
\hline
\end{tabular}

(Source-Field Study)

Interpretation: Considering the total sample of 30 people in Hirbandh block, 6 people are

found to be illiterate and from them 4 people belong to the age group of fifty, 1 person belongs to the age group of $30-40$ and the last one belongs to the age group of 20-30; 5 people have completed only primary education and from them 4 people belong to the age group of 50 and 1 person belongs to the age group of 20-30;12 people have passed their matric examination and from them 2 people belong to the age group of 50,5 people belong to the 40-50, 3 people belong to the age group of 30-40 and finally 2 people belong to the age group of $20-30 ; 5$ people have completed higher secondary (+2) examination and from them 2 people belong to the age group of $40-50$ and 3 
people belong to the age group of 30-40; only 2 people have completed graduation from the age group of 30-40. No people have been found who have gone for the post-graduation courses.

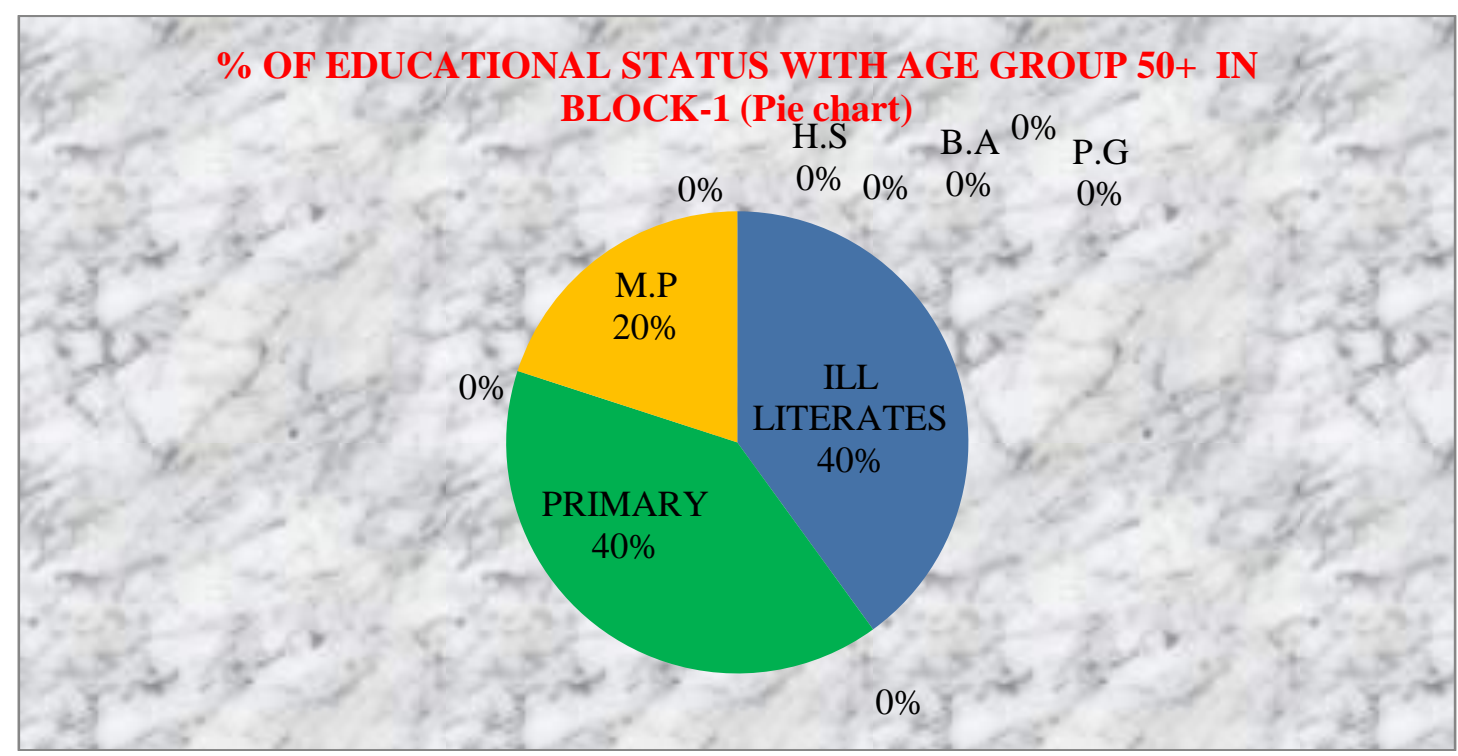

Figure-3 (Source-Field Study)

\section{\% OF EDUCATIONAL STATUS WITH AGE GROUP 40-} 50 IN BLOCK-1 (Pie chart)

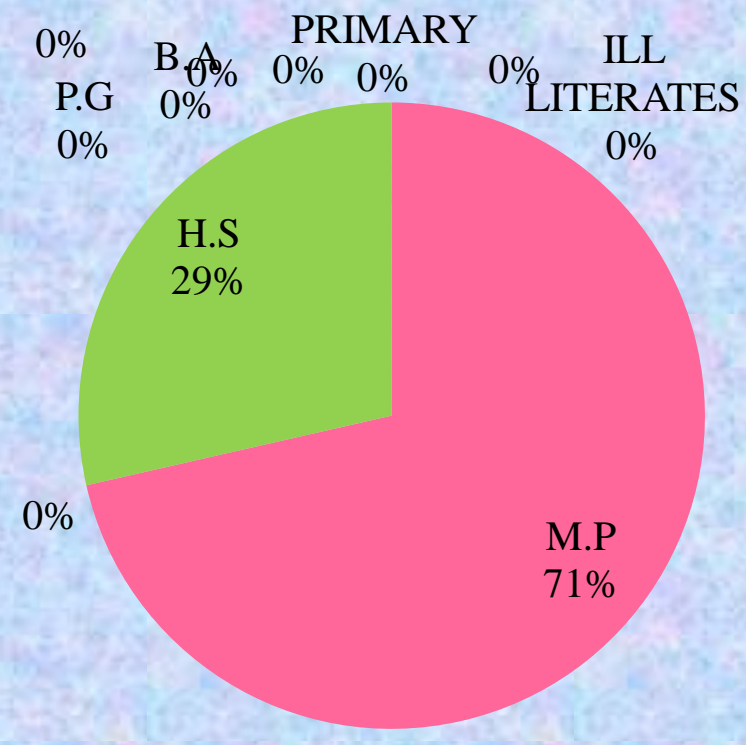

Figure 4 Source: Field Study 


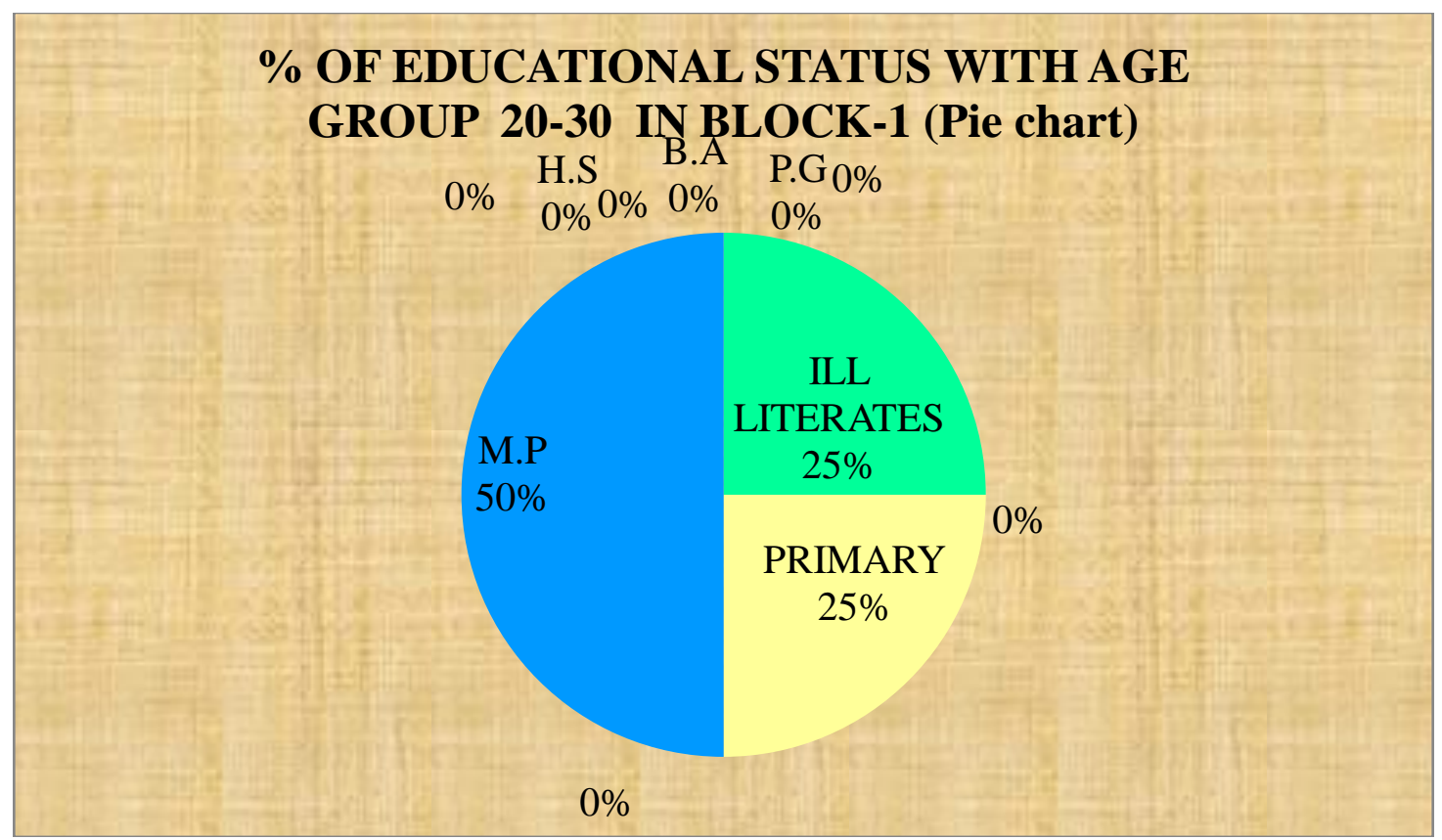

Figure-5 (Source-Field Study)

Table 3: Educational Status of Kora Community of Chatna Block, Bankura district

\begin{tabular}{|l|l|l|l|l|l|l|}
\hline BLOCK-2 (Chatna) & Mrimary & M.P & H.S & B.A & P.G & Total \\
\hline Illiterates & P.G & 12 & 4 & 2 & 1 & 30 \\
\hline 5 & 6 & &
\end{tabular}

(Source-field study)

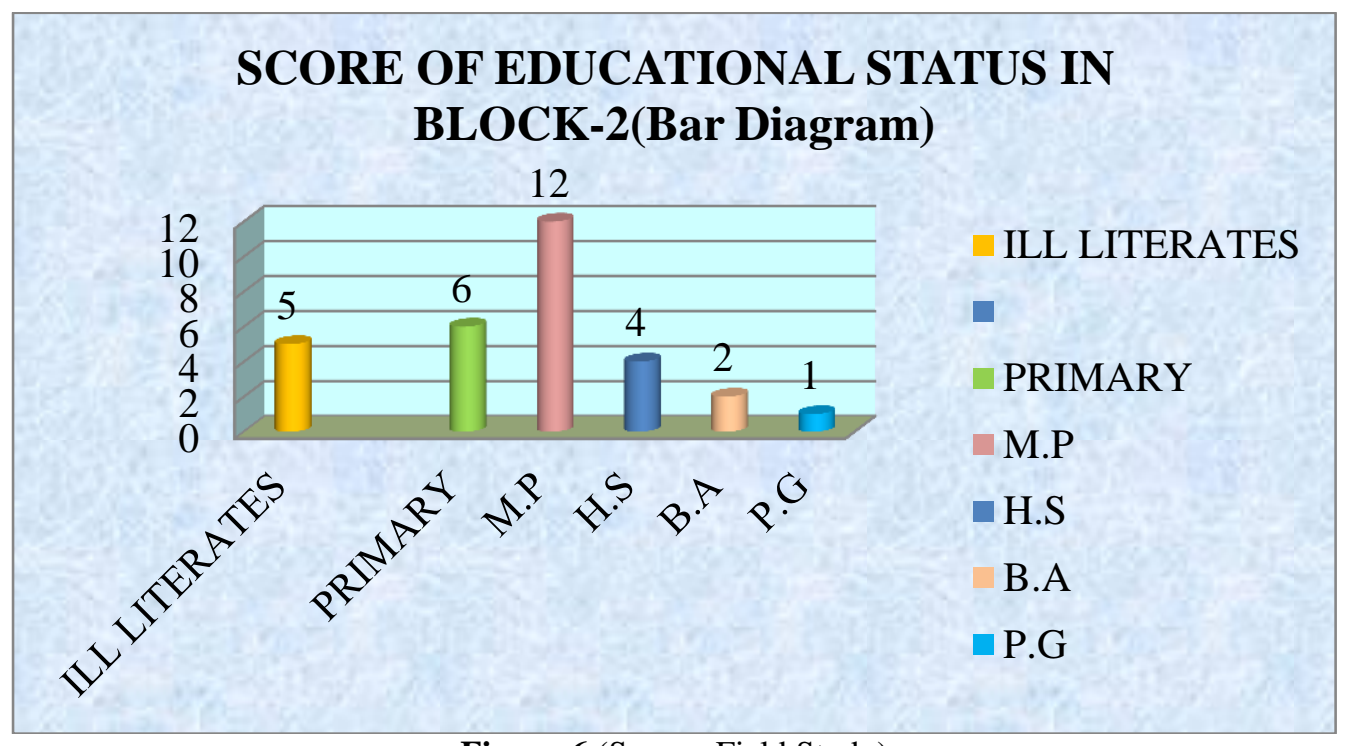

Figure-6 (Source-Field Study) 


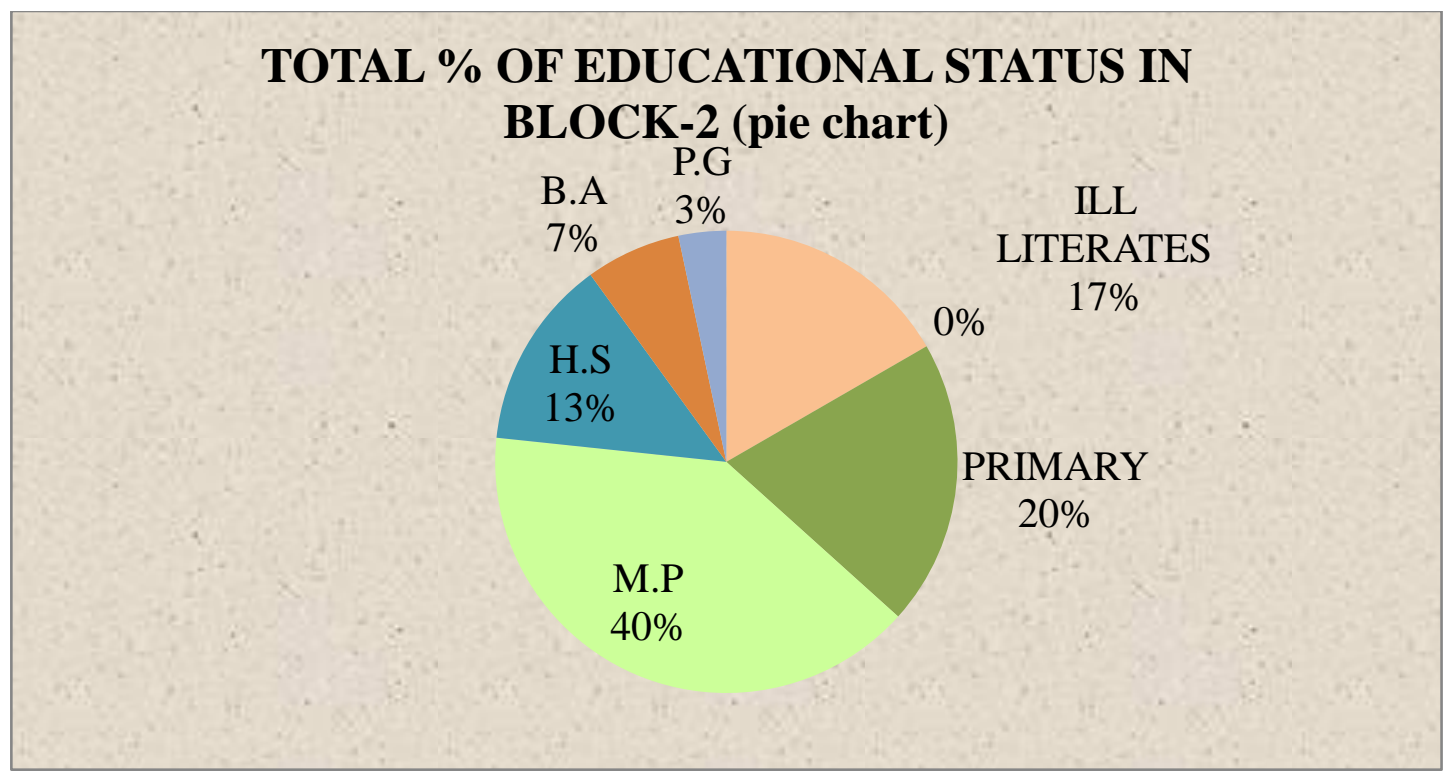

Figure- 7 (Source-Field Study).

Table 4: Educational Status With Various Age Group Chatna Block, Bankura district

\begin{tabular}{|l|l|l|l|l|l|l|}
\hline Educational Status With Various Age Group Chatna Block \\
\hline Age Group & Illiterates & Primary & M.P & H.S & B.A & P.G \\
\hline 50 & 4 & 3 & 0 & 0 & 0 & 0 \\
\hline $40-50$ & 1 & 2 & 6 & 0 & 1 & 0 \\
\hline $30-40$ & 0 & 0 & 5 & 1 & 0 & 1 \\
\hline $20-30$ & 0 & 1 & 1 & 3 & 1 & 0 \\
\hline TOTAL-30 & & \multicolumn{5}{l|}{} \\
\hline
\end{tabular}

Source: Field Study

\section{Interpretation:}

Considering the total sample of 30 people in Chatna block, 5 people are found to be illiterate and from them 4 people belong to the age group of fifty, 1 person belongs to the age group of 30-40; 6 people have completed only primary education and from them 3 people belong to the age group of 50, 2 people belong to the age group of 40-50 and 1 person belongs to the age group of 20-30; 12 people have passed their matric examination and from them 6 people belong to the 40-50, 5 people belong to the age group of 30-40 and finally 1 person belongs to the age group of 20-30; 4 people have completed higher secondary $(+2)$ examination and from them 1 person belongs to the age group of 30-40 and 3 people belong to the age group of 20-30; only 2 people have completed graduation from the age group of 40-50 (one) and 20-30 (one). Only one person has been found who have gone for the post-graduation course from the age group of 30-40. 


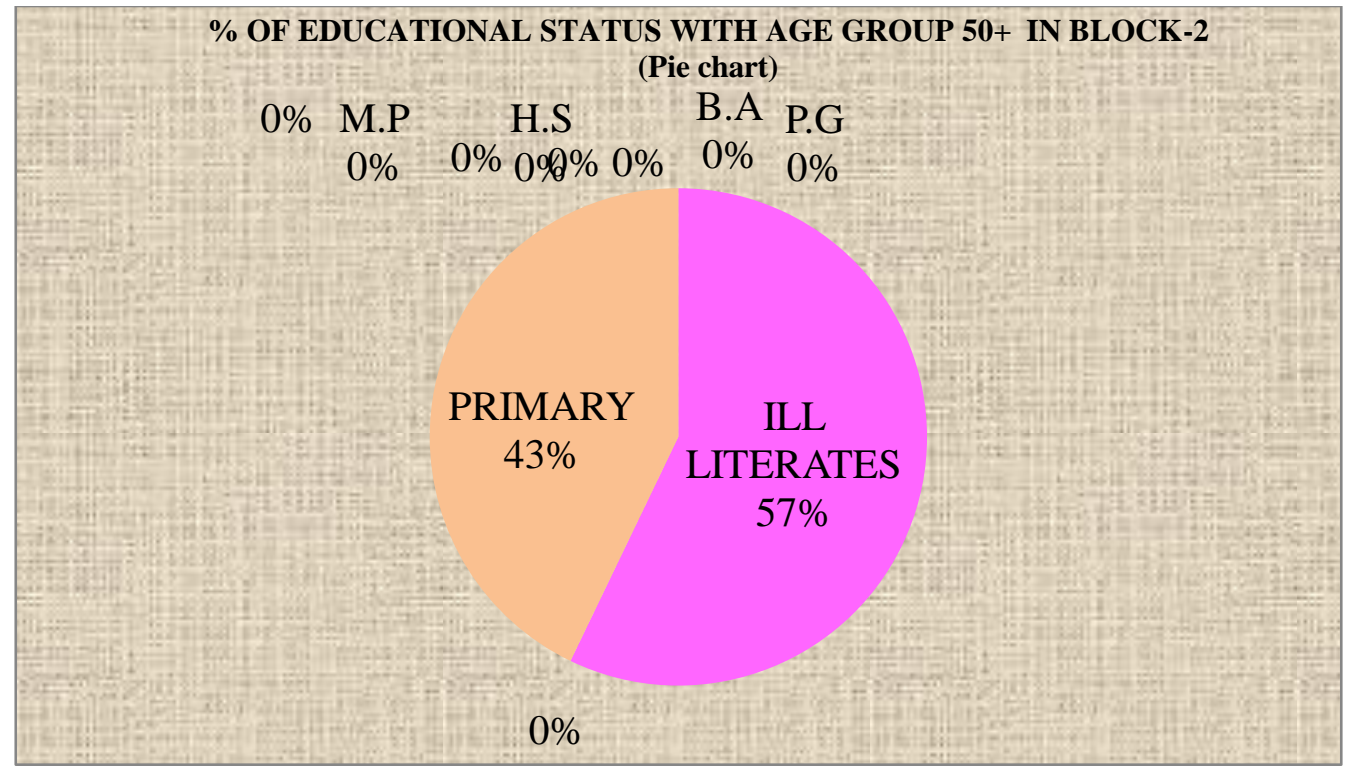

Figure 8:-(Source-Field Study).

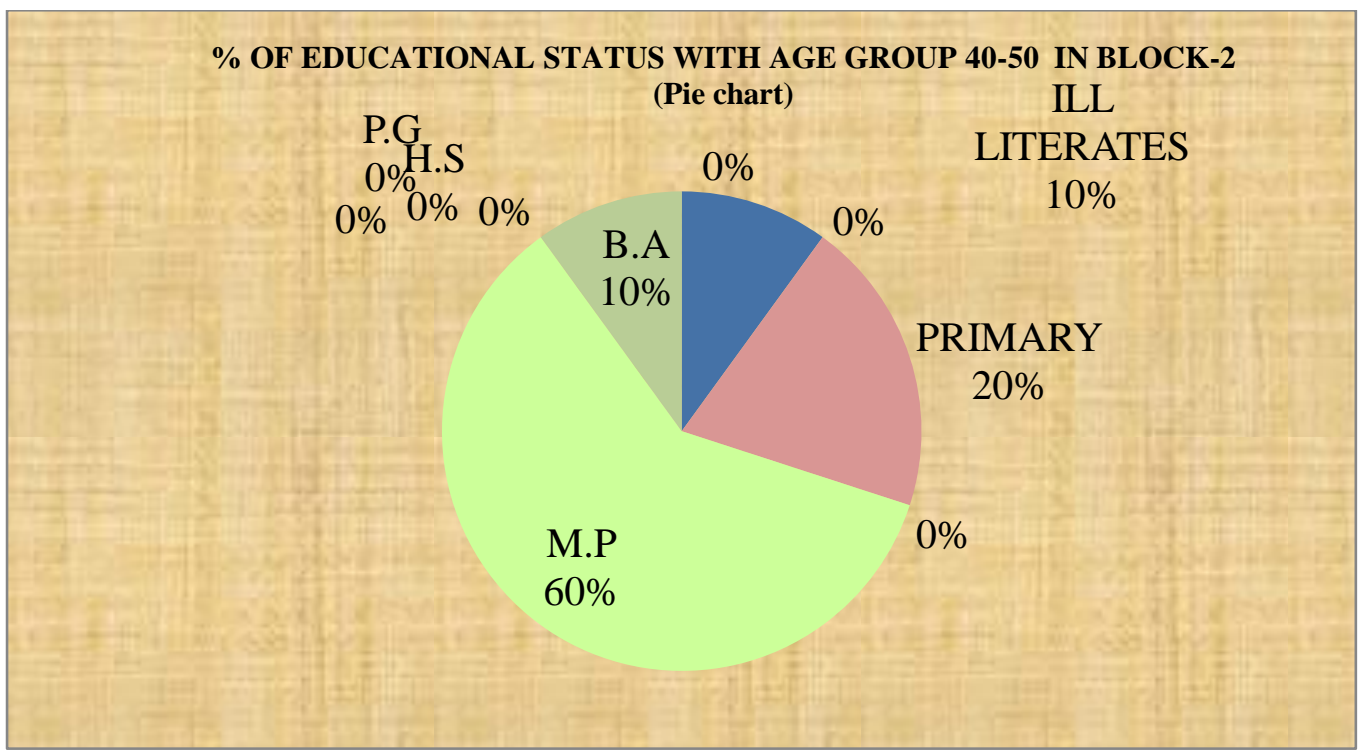

Figure 9:-(Source-Field Study).

Table 5: Educational Status of Kora community of Puncha Block, Puruliya District

\begin{tabular}{|l|l|l|l|l|l|l|}
\hline BLOCK-3 (PUNCHA) & M.P & H.S & B.A & P.G & Total \\
\hline Illiterates & Primary & M.P & 0 & 0 & 30 \\
\hline 9 & 12 & 7 & 2 & 0 & \\
\hline
\end{tabular}

(Source-Field Study) 


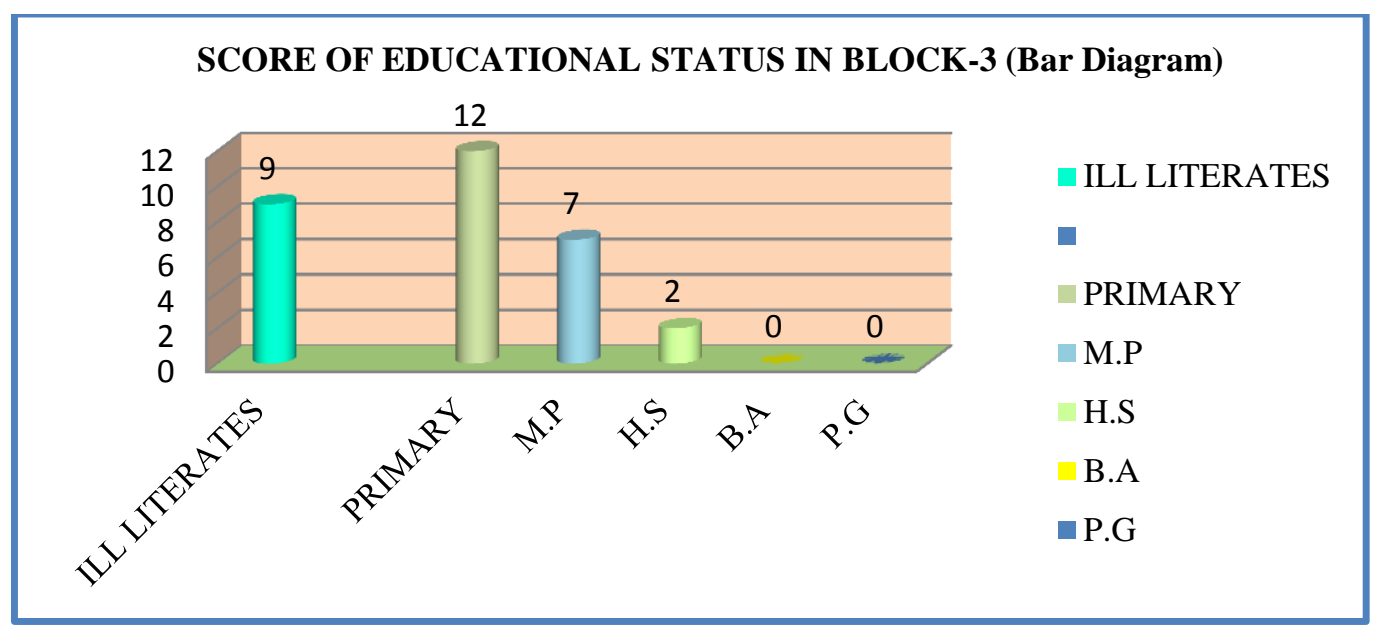

Figure 10:-(Source-Field Study)

Table 5:-Educational Status With Various Age Group Puncha Block, Puruliya District

\begin{tabular}{|l|l|l|l|l|l|l|l|}
\hline Educational Status With Various Age Group Puncha Block \\
\hline Age Group & Illiterates & Primary & M.P & H.S & B.A & P.G \\
& & & & & & \\
\hline 50 & 8 & 7 & 4 & 1 & 0 & 0 \\
\hline $40-50$ & 1 & 7 & 0 & 0 & 0 & 0 \\
\hline $30-40$ & 0 & 0 & 1 & 0 & 0 & 0 \\
\hline $20-30$ & 0 & 1 & 2 & 1 & 0 & 0 \\
\hline TOTAL- 30 & & & \\
\hline
\end{tabular}

Table-12(Source-Field Study)

\section{Interpretation:}

Considering the total sample of 30 people in Puncha block, 10 people are found to be illiterate and from them 8 people belong to the age group of 50,1 person belongs to the age group of 40-50 and 1 person belongs to the age group of 30-40; 12 people have completed only primary education and from them 4 people belong to the age group of 50, 7 people belong to the age group of 40-50 and 1 person belongs to the age group of 20-30; 6 people have passed their matric examination and from them 4 people belong to the age group of 50 and 2 people belong to the age group of 20-30; 2 people have completed higher secondary (+2) examination and from them 1 person belongs to the age group of 50 and 1 person belongs to the age group of 20-30. No people have been found who have gone for the graduation and post-graduation courses.

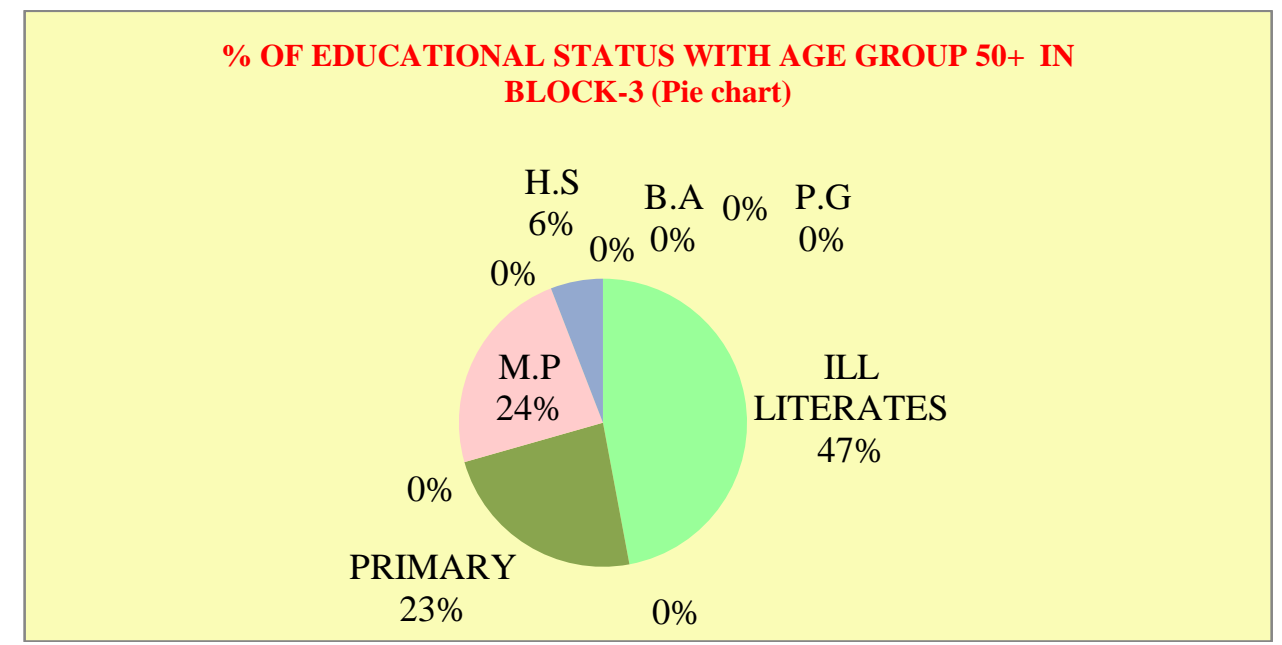

Figure 11:-(Source-Field Study) 


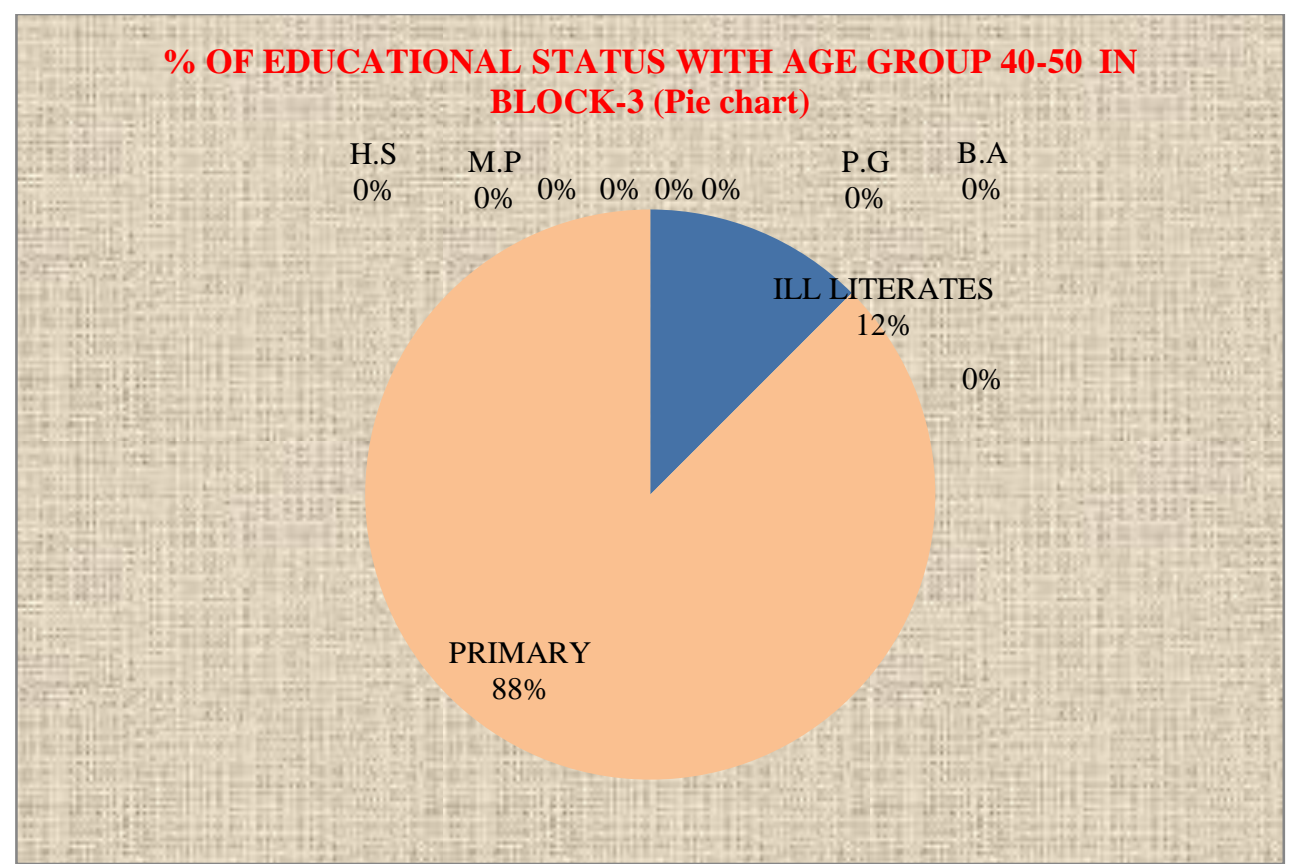

Figure 12:-(Source-Field Study).

\section{\% OF EDUCATIONAL STATUS WITH AGE GROUP 30-40} IN BLOCK-3 (Pie chart)

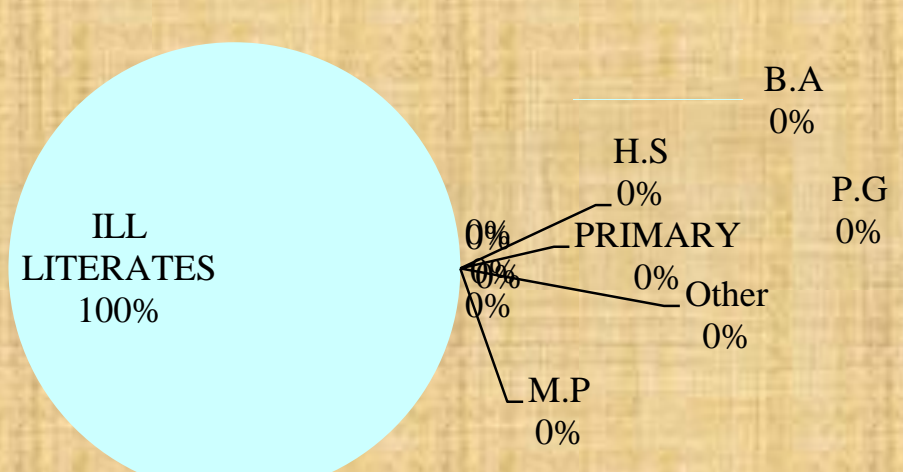

Figure 14:-(Source-Field Study) 


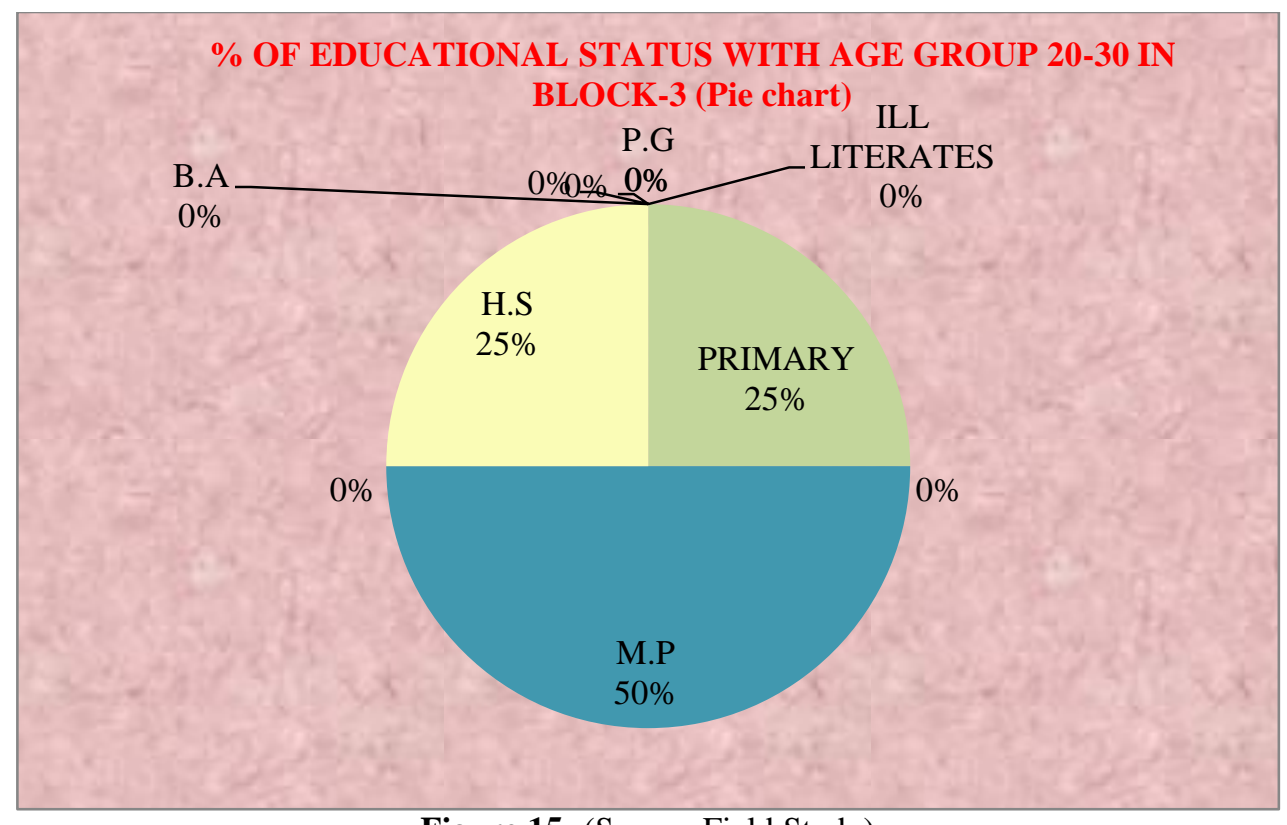

Figure 15:-(Source-Field Study)

Table 6:-Educational Status of Kora Community of Manbazar block, Purulia District

\begin{tabular}{|c|c|c|c|c|c|c|}
\hline Illiterates & Primary & M.P & H.S & B.A & P.G & Total \\
\hline 8 & 10 & 9 & 2 & 1 & 0 & 30 \\
\hline
\end{tabular}

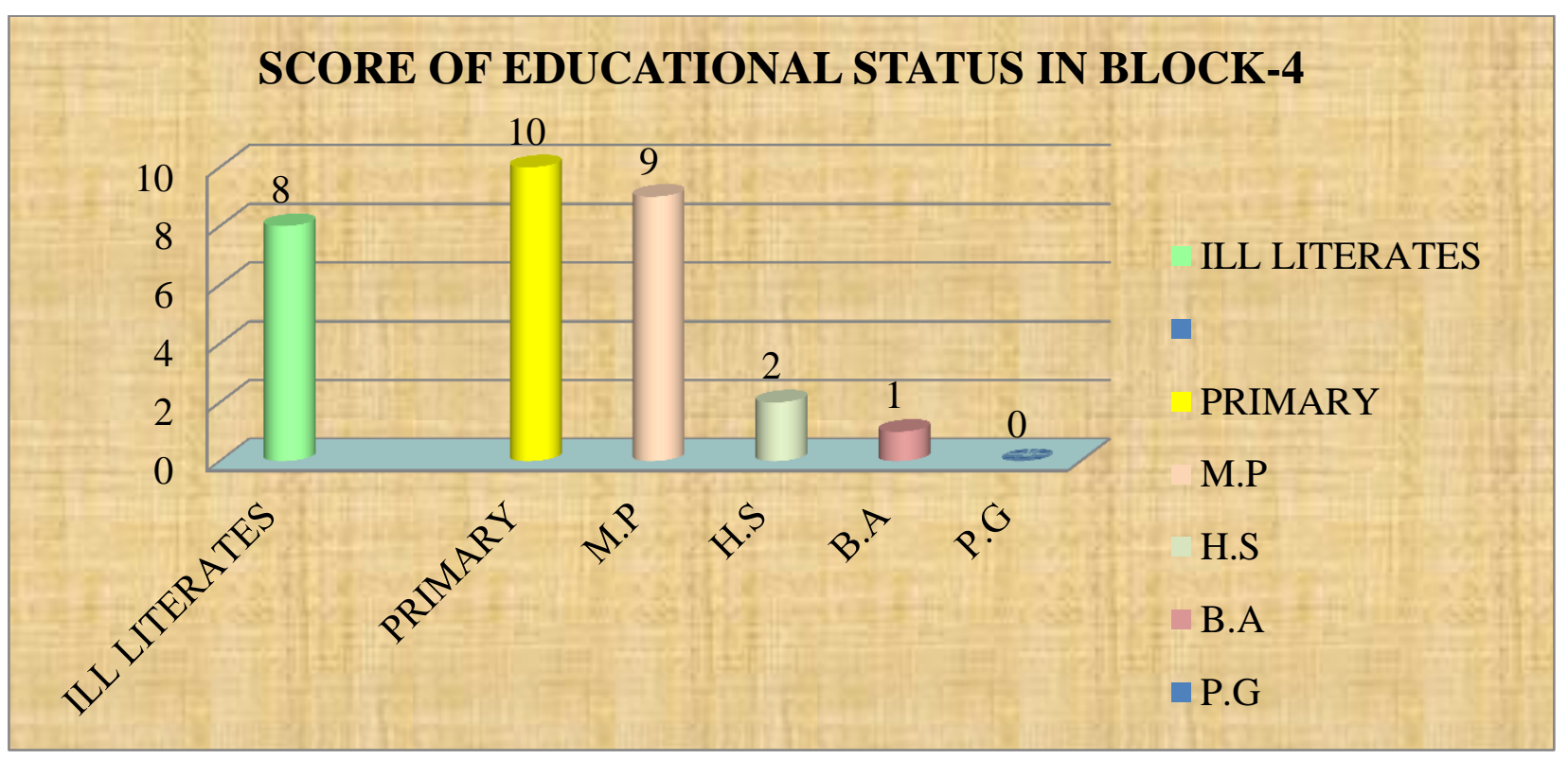

Figure 16:-(Source-Field Study) 


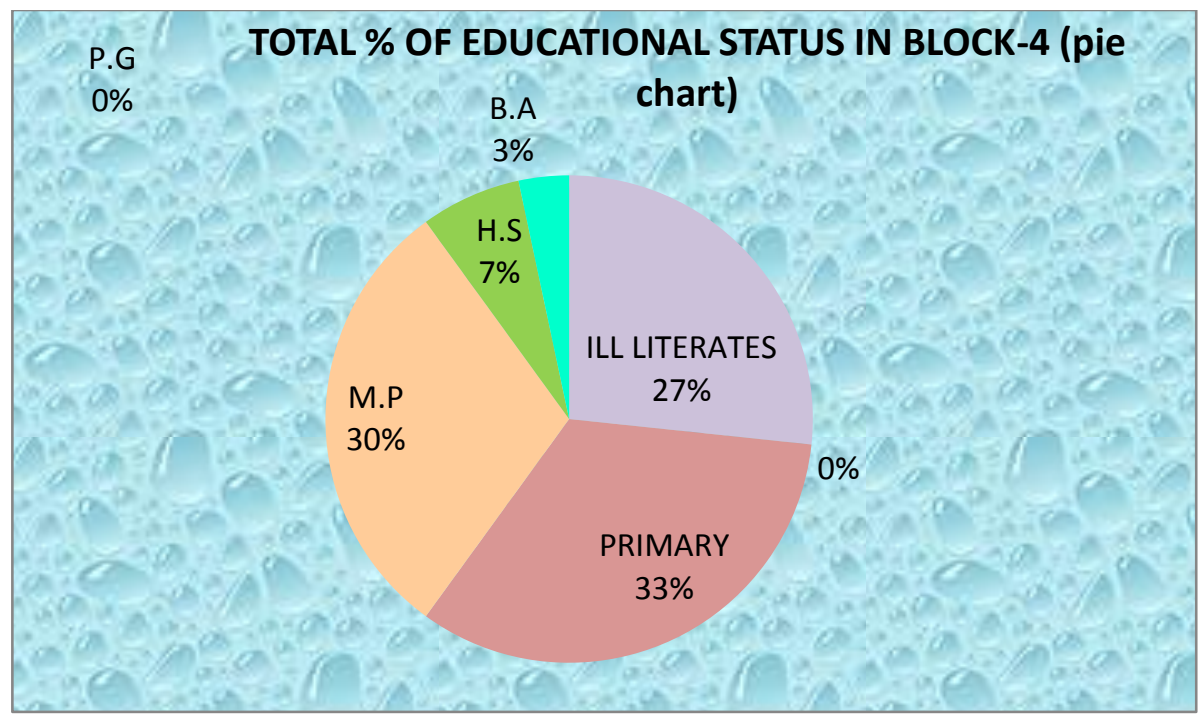

Figure-17 (Source-Field Study)

Table-7: Educational Status With Various Age Group Manbazar Block

\begin{tabular}{|l|l|l|l|l|l|l|l|}
\hline \multicolumn{2}{|l|}{ Educational Status With Various Age Group Manbazar Block } \\
\hline Age Group & Illiterates & Primary & M.P & H.S & B.A & P.G & Total \\
\hline 50 & 6 & 0 & 0 & 0 & 0 & 0 & 6 \\
\hline $40-50$ & 2 & 5 & 0 & 0 & 0 & 0 & 7 \\
\hline $30-40$ & 0 & 4 & 5 & 0 & 1 & 0 & 10 \\
\hline $20-30$ & 0 & 1 & 4 & 2 & 0 & 0 & 7 \\
\hline Total & 8 & 10 & 9 & 2 & 1 & 0 & 30 \\
\hline
\end{tabular}

Source: Field Study

\section{Interpretation:}

Considering the total sample of 30 people in Manbazar block, 8 people are found to be illiterate and from them 6 people belong to the age group of 50 and 2 people belong to the age group of $40-50 ; 10$ people have completed only primary education and from them 5 people belong to the age group of 40-50, 4 people belong to the age group of 30 40 and 1 person belongs to the age group of 20-30; 9 people have passed their matric examination and from them 5 people belong to the age group of 30-40 and 4 people belong to the age group of 20-30;2 people have completed higher secondary (+2) examination from the age group of 20-30 and 1 person has been found who has completed graduation course from the age group of 30-40. No person has been found who has gone for the post-graduation course.

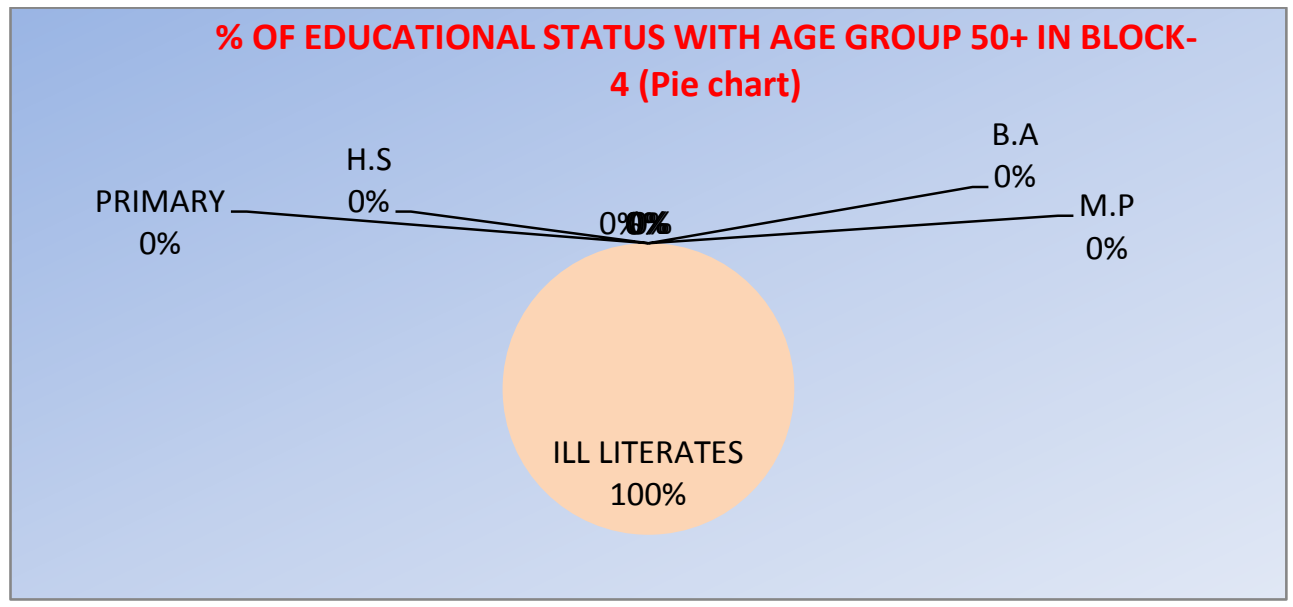

Source-field study

Figure 18:-(Source-Field Study) 


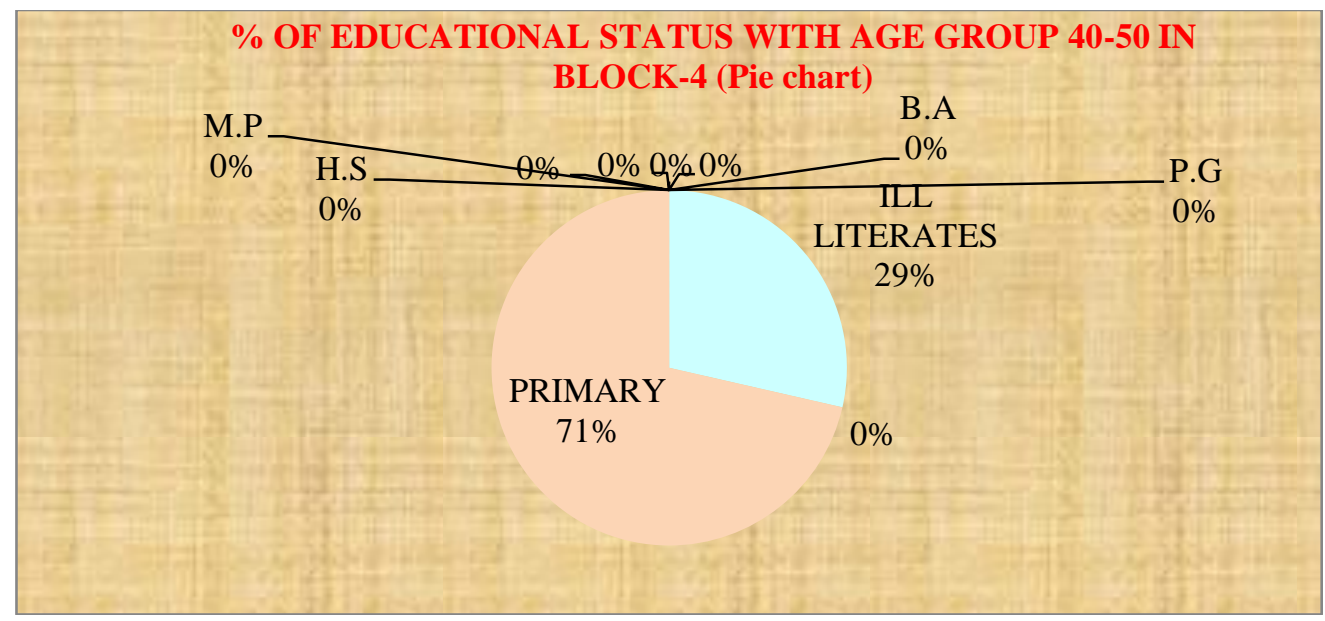

Figure 19:-(Source-Field Study).

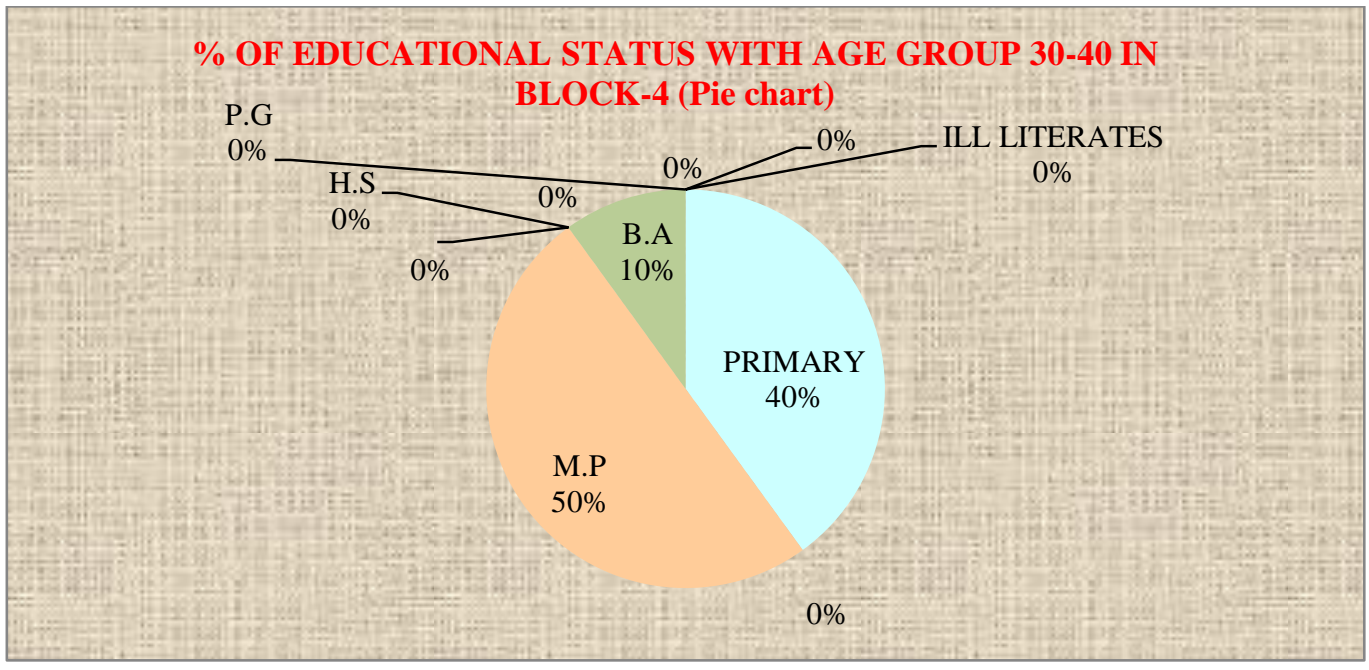

Figure 20:-(Source-Field Study)

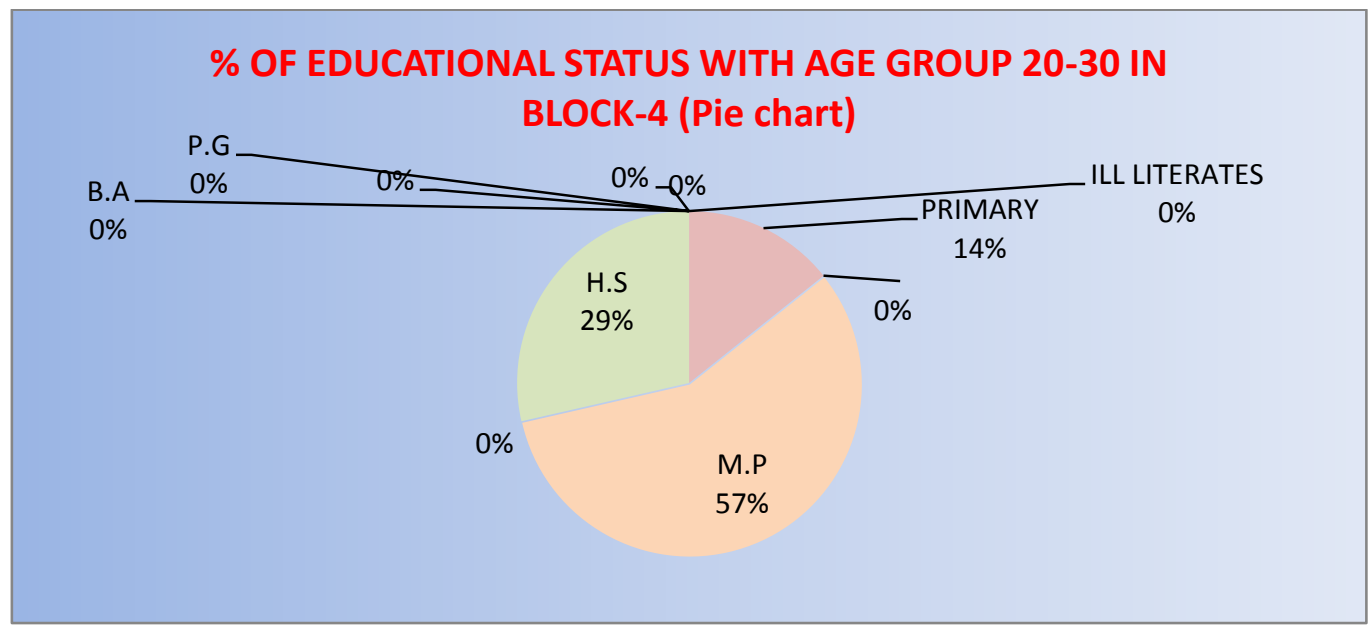

Figure 21:-(Source-Field Study).

\section{Conclusion:-}

In Purulia district found that lack of higher education in Puncha block, maximum people have limited education which delimited up to elementary level and old aged Kora peoples are illiterate, but some old aged people completed only primary level. In Manbazar block found that $27 \%$ people are illiterate, 33\% in primary level,30\% was 
completed secondary level and only $10 \%$ peoples are graduate. There have many causes for this condition like poverty, lack of income source, separation of other community, isolated forest area, lack of consciousness and malnutrition. Few number of people completed higher secondary level, they have also lived in school or college hostel. They have need to economic support and proper guidance. Educated Kora people adopted some modern culture and education leads to their social mobility and cultural change. . Education also leads to better living and for better livings migration or relocation of population is amplified. Tribal culture is undergoing a rapid change under the in hence of Education. This change has affected 'KORA' livelihood, their social stratification - mobility, their culture rituals and how far they are concerned with their own culture- traditions, rituals, religions belief and so on.

\section{Reference:-}

1. Ahluwalia, B.K. \& Ahiuwalia, S. (1986). Social and Economic Development in North East India. Delhi: Gain Publishing House.

2. Ahmed, A. (1987). The Anatomy of Rural Poverty in Assam. Delhi: Mittal Publications.

3. Arsenberg, C.M. \& Niehoft, A. H. (1964). Introducing Social Change. Chicago: Aldine.

4. Backward Class Welfare (BCW) department: Govt. of West Bengal, Census 2001. Retrieve 15 january2018 from

http://wbpar.gov.in/writereaddata/WB\%20SC\%20\&\%20ST(Reservation\%20of\%20vacancies\%20in\%20the\%20 services\%20and\%20post)Act,\%201976_b.pdf

5. Beals, R.L., Hoijer, H. \& Beals, A.R. (1977). An Introduction to Anthropology. New York: Mac Millan Publishing Co. Ltd.

6. Cochrane, G. (1971). Development anthropology. New York: Oxford University Press.

7. Coffey, A. (1999). The Ethnographic Self: Fieldwork and the Representation of Identity. London: Sage.

8. Danda, A.K. (1991). Tribal economy in India. New Delhi: Inter India Publications.

9. Das, B.M. (1987). The Peoples of Assam. Delhi: Gain Publishing House.

10. Das, D. R. (1990). Tribal Situation in West Bengal, KLM, Calcutta. Delhi: Gain Publishing House.

11. Das, S. \& Bose, K. (2009) Anthropometric Characteristics and Nutritional Status of Bauri Pre-School Children of Nituria Block, Purulia, West Bengal", Intern. J. Biol. Anthropol., Vol. 3, No- 2.

12. Ghosh, R, Bharati, P. (2006). Nutritional status of adults among Munda and Pod populations in a Semi-Urban Area of Kolkata City, India. Asia Pac J Public Health.

13. Ghosh, S. Malik, S. L.(2007). Sex Differences in Body Size and Shape Among Santhals of West Bengal. House.

14. https://www.culturalsurvival.org/publications/cultural-survival-quarterly/tribal-education-india

15. https://www.indiatoday.in/education-today/featurephilia/story/tribal-education-and-its-challenging-issues-inindia-965832-2017-03-16. Retrieved on: 26.01.2018 